\title{
Joint Security Cooperation or Regional Disintegration? Why the West Should Engage Russia in Central Asia
}

\author{
By Egor Evsikov and Leonid Shafir*
}

In the West, Russian influence in the post-Soviet realm is often perceived in a negative light. In the case of Central Asia, Russia is often held responsible for trying to minimize Western involvement in region viewed by Moscow to be its "back yard." According to this view, Russian influence in Central Asia hampers the Western "war on terrorism" in Afghanistan and also props up corrupt authoritarian regimes in regional capitals, which hinders the region's economic and political development. Typical of this worldview is the work of Stephen Blank, who considers the Russian resurgence in Central Asia dangerous for the West and holds Moscow responsible for the "consolidation of authoritarian regimes" in Central Asia. ${ }^{1}$ Scholars and policymakers who share this view see Russia as a rival who competes with the West for influence in Central Asia because of its geostrategic location and energy resources. However, this attitude ignores the fact that Central Asia faces multiple security threats, and also increases the danger of rivalry between the West and Russia. This approach is counterproductive, as it can fuel instability in the already volatile region. The necessity of cooperation with Russia in the region is advocated by a number of more pragmatic scholars and policymakers, including Zbigniew Brzezinski, who is otherwise known for his tough stance towards Moscow. In his key work The Grand Chessboard, he states in regards to Central Asia that "the exclusion of Russia from the area is neither desirable nor feasible." ${ }^{2}$

This article demonstrates the crucial importance of a new level of cooperation between Russia and the West in Central Asia, the need for outside security assistance and guidance in the region, as well as the shortcomings of the "going it alone" attitude.

* Egor Evsikov is a member of the Canadian Armed Forces and has a Master's Degree in War Studies from the Royal Military College of Canada. Leonid Shafir is a former desk officer at the Canadian Department of Foreign Affairs and International Trade and has recently graduated with a Master's Degree in Public Administration with a dual concentration in Policy Analysis and International Development from Carleton University of Ottawa; he also has a Master's Degree in Religion and Cultural Studies from Wilfrid Laurier University of Waterloo, ON, Canada.

1 Stephen Blank, "The Strategic Importance of CA: An American View," Parameters (Spring 2008): 78.

2 Zbignew Brzezinski, The Grand Chessboard: American Primacy and its Geostrategic Imperatives (New York: Basic Books, 1997), 149. 
This necessity is shown using the example of post-Soviet Kyrgyzstan, where state failure is a distinct possibility that presents a grave risk to regional stability. The article starts with a historic overview of Kyrgyzstan and an analysis of the major external and internal security threats facing the country and Bishkek's limited ability to deal with these threats on its own. This is followed by an overview of Russian and Western security initiatives in Central Asia, which shows the limitations of these security initiatives to date and discusses scenarios of regional instability that the status quo can cause. The article concludes with an outline of possible modes of security cooperation between Russia and the West to avert present and future threats and maintain peace and stability in Central Asia.

\section{Kyrgyzstan: Historical Overview}

The lands of modern Kyrgyzstan were among the early cradles of human civilization. In ancient and early medieval times the territory of today's Kyrgyzstan was under the control of various Persian and Turkic empires, with settled life confined mostly to the fertile lands of Fergana Valley. In the 1850s and 60s, Kazakh and Kyrgyz tribes sided with the Russians against the khans of Kokand, and Kyrgyzstan became part of Russian Turkestan. The sparsely populated lands of northern Kyrgyzstan attracted many settlers from the European part of the Russian Empire. This trend continued during the Soviet period, when industrial development concentrated mostly in the north of the Kyrgyz Soviet Socialist Republic (Kyrgyz SSR) in and around Frunze (as Bishkek was called between 1926 and 1991), bringing additional numbers of European (mostly ethnic Russian) migrants. Between 1939 and 1959 the number of Russians increased from 302,900 to 623,500, most of who settled in Frunze and the Chui region of northern Kyrgyzstan. These migrations, in addition to an existing Uzbek minority, made the republic among the most ethnically diverse in the Soviet Union. In fact, before 1985 ethnic Kyrgyz made up less than half of the republic's population. ${ }^{3}$

Following the collapse of the Soviet Union, the Central Asian republics were forced to become independent nations. In Kazakhstan, Uzbekistan, and Turkmeni-

3 During the Second World War many industrial facilities and their employees were evacuated from the European part of the Soviet Union to the Central Asian republics, including the Kyrgyz SSR. In addition, Stalin's deportations of various Soviet ethnic minorities in the 1930s and 1940s brought an additional influx of ethnic Koreans, Meshetian Turks, Germans, and Kurds, while the Chinese Civil War and Mao's Cultural Revolution forced a number of Chinese Uighurs to cross the border of the USSR and settle in Kyrgyzstan. See Haluk Alkan, "Post-Soviet Politics in Kyrgyzstan: Between Centralism and Localism?" Contemporary Politics 15:3 (September 2009): 358. 
stan, local Communist Party bosses managed a stable transfer of power and became autocratic nationalist presidents of newly independent states. Meanwhile, Tajikistan collapsed into a bloody civil war. The situation in Kyrgyzstan was unique, resembling more that of the Eastern European post-Communist states, rather than of the general state of affairs Central Asia. In October 1991, Askar Akayev, an academic who was not a Communist Party apparatchik, was confirmed by popular vote as the first president of independent Kyrgyzstan. ${ }^{4}$ However, in reality this was not a democratic success story, but rather a compromise in a power struggle between Kyrgyz clans. This mode of clan-based politics was indicative of nepotism, corruption, and a culture of kinship that had been entrenched in Central Asia since late Soviet times. ${ }^{5}$

The first years of Kyrgyz independence did result in a more liberal and democratic regime compared to the authoritarian regimes that emerged in other Central Asian states. In the early 1990s some Western observers even described Kyrgyzstan as a Central Asian "little Switzerland," an island of democracy surrounded by a sea of authoritarianism. ${ }^{6}$ This relative liberalism was due to several factors, including Akayev's personality, but more importantly due to many obstacles that prevented the creation of a centralized authoritarian regime in Kyrgyzstan, including its geography, multiethnic character, regional fragmentation, clan-based society traditions, and history of nomadic tribalism.

From the early days of independence Kyrgyzstan faced serious security challenges that not only threatened its stability but also had the potential to undermine its viability as a state. The security threats facing Kyrgyzstan were both internal and external. Major external security threats included Islamist extremism and heroin drug-trafficking emanating from Kyrgyzstan's war-ravaged neighbors Afghanistan and Tajikistan. The major internal security threats to Kyrgyzstan were ethnic tensions and organized crime closely linked to the transnational threats and amplified by corruption, regionalism, and clan-based nepotism. These challenges were the primary factors behind the gradual rollback of liberalism under President Akayev in the late 1990s and early 2000s, when his increasingly weak regime struggled to effectively confront these threats. By 2010 they had transformed a relatively stable state - one that Western observers touted as the best hope for economic and political modernization in Central Asia - into a highly unstable nation plagued by political violence and ethnic riots that brought Kyrgyzstan close to the brink of state failure.

\footnotetext{
4 Kathleen Collins, Clan Politics and Regime Transition in Central Asia (New York: Cambridge University Press, 2006), 126-27.

5 Ibid., 106.

6 Ibid., 175.
} 


\section{Security Threats: External and Internal Challenges to Kyrgyz State- hood}

The specter of Islamist extremism is arguably the top external security threat currently facing Central Asia. This security threat is especially relevant for the two most fragile states of Central Asia-Kyrgyzstan and Tajikistan - and to a lesser extent for Uzbekistan. ${ }^{7}$ Islamist extremism in Central Asia is represented first and foremost by two organizations: Hizb ut-Tahrir (HT) and the Islamic Movement of Uzbekistan (IMU).

Hizb ut-Tahrir is an extremist but allegedly nonviolent organization that was founded in 1952 by a Palestinian Islamic scholar, Taqiuddin al-Nabhani. Hizb ut-Tahrir followers promote an extremely conservative interpretation of Islam along the lines of the Wahhabi, Salafi, and Deobandi sects. Hizb ut-Tahrir's goal is for all Muslim countries to unify as an Islamic caliphate ruled by sharia law. Although the organization itself is rarely involved in violent activities, it nonetheless ideologically supports Islamist insurgencies and terrorism, and its worldview is generally aligned with that of Al Qaeda. Because Hizb ut-Tahrir is banned in all of the Central Asian states, it is highly secretive. ${ }^{8}$

The Islamic Movement of Uzbekistan was founded as the Islamist group Adolat [Justice] in the early 1990s by Juma Namangani and Tahir Yuldashev. Namagani and Yuldashev were both ethnic Uzbeks from Namangan. They allegedly rediscovered their Muslim faith while fighting in Afghanistan in the 1980s as Soviet soldiers. Like Hizb ut-Tahrir, the Islamic Movement of Uzbekistan draws most of its supporters from the heavily populated Fergana Valley. Its original objective was the overthrow of President Islam Karimov of Uzbekistan, but their goals later evolved into establishing an Islamic super-state in Central Asia. Between 1992 and 1997, the IMU fought in Tajikistan's civil war on the side of the Islamists, and after 1997 allied with Al Qaeda and operated out of bases in Tajikistan's Rasht Valley and Taliban-controlled

7 Uzbekistan inherited and maintained elaborate security structures from the Soviet Union and had more resources at its disposal to deal with Islamist extremism. Erica Marat, The Military and the State in Central Asia: From Red Army to Independence, (London: Routledge, 2010), 1-2.

8 Outside of Central Asia, Hizb ut-Tahrir is banned in some countries like Russia, Turkey, and Germany, while it operates legally in others, such as the United Kingdom, Pakistan, and Malaysia. Hizb ut-Tahrir is largely supported by young Uzbeks and to a lesser extent Tajiks from the Fergana Valley with cells in towns such as Namangan, Andijon, Kokand, and Feghana in Uzbekistan; Khujand and Isafara in Tajikistan; and Osh and Jalal-Abad in Kyrgyzstan. Reuel R. Hanks, Global Security Watch - Central Asia (Santa Barbara, CA: ABC-CLIO, 2010), 55-56. 
areas of northern Afghanistan. ${ }^{9}$ Following the U.S. invasion of Afghanistan in the fall of 2001, the Islamic Movement of Uzbekistan suffered many casualties and fled to Pakistani border regions including North and South Waziristan and Federally Administered Tribal Areas (FATA). ${ }^{10}$ The IMU is still active in the Pakistan-Afghanistan border region, and has recently once again resurfaced in its old strongholds of northern Afghanistan and was linked to a series of terrorist attacks in Tajikistan and Kyrgyzstan.

Despite the contrast between the nonviolent strategy of Hizb ut-Tahrir and the militant strategy of the Islamic Movement of Uzbekistan, these two main extremist Islamist organizations in Central Asia are closely linked to each other as well as to the Afghan Taliban and various Islamist extremist organizations in Pakistan such as Al Qaeda and Tehrik-i-Taliban Pakistan (TTP). ${ }^{11}$ Often Islamists in Central Asia are members of both organizations, while in other cases Hizb ut-Tahrir works as the first "school" that indoctrinates young extremists who later join the IMU. The supporters of both organizations are overwhelmingly ethnic Uzbeks, with some Tajiks and only a small fraction of other major Central Asian ethnic groups such as Kazakhs, Turkmen, and Kyrgyz. Because of effective (if often brutal) state surveillance and repression against Islamists in Uzbekistan, many Uzbek Islamist extremists sought refuge in both Tajikistan and Kyrgyzstan, where sizable ethnic Uzbek minorities live (around 1.1 to 1.4 million in Tajikistan, and 720,000 to 1.5 million in Kyrgyzstan).

Tashkent and Bishkek have often been accused of repressive policies towards devout Muslims, whom its security services often label as extremists. Many Western observers also claim that these heavy-handed policies make the problem worse by driving pious Muslims into the hands of Islamist groups. Central Asian regimes are also often accused of exaggerating the security threat posed by the Islamist extremists in order to justify their autocratic policies and to receive financial aid for their role in the global war against terrorism. ${ }^{12}$ While some of these claims might have some merit, they downplay the genuine security challenge from Islamist extremists faced by Central Asian states. These challenges were not invented by local political leaders, but grew due to many complex factors, including the spillover effects of the Afghan conflict, the decline of Central Asian socioeconomic standards, rapid demographic changes, the revival of political Islam throughout the Muslim world, and increasing foreign influences radiating from Pakistan, Saudi Arabia, Iran, and other countries.

\footnotetext{
Ibid., 54.

10 Allegedly, the IMU escaped with help from the Pakistani intelligence services (ISI), who sheltered and funded the IMU. See Ahmed Rashid, Descent into Chaos: The United States and the Failure of Nation Building in Pakistan, Afghanistan, and Central Asia (New York: Viking, 2008), 164.

11 Ibid., 347.

12 Hanks, Global Security Watch-Central Asia, 66-67.
} 
Another major external security threat to Central Asia as a whole and to Kyrgyzstan in particular is the trafficking of illicit drugs, especially Afghan heroin. Around 90 percent of world's heroin supply originates in Afghanistan, and proximity to this country plays a central role in the narco-criminalization of Central Asia. Almost all of the major Central Asian organized crime groups are involved in smuggling illegal drugs from Afghanistan. The Central Asian narco-mafia is well integrated into the global network of the illegal drug trade. Most Afghan heroin is first smuggled across the Afghan-Tajik and Afghan-Turkmen borders, and later trafficked via Kyrgyzstan, Uzbekistan, and Kazakhstan on to its major final destinations - industrial cities across Russia, as well as Ukraine and the European Union. Kyrgyzstan is also a major hub for Afghan heroin destined for China, especially Xinjiang Province, where heroin addiction is rampant. ${ }^{13}$ The role of the "northern route" for Afghan heroin has gradually increased over the last decade. ${ }^{14}$ Narcotics trafficking is a real threat to the security of Kyrgyzstan, with roughly 20 to 60 metric tons of heroin being trafficked through Kyrgyzstan annually. ${ }^{15}$ Drug-related criminal activities penetrate all levels of society in Kyrgyzstan, and the criminal nexus involves many corrupt government officials. Without international assistance, Kyrgyzstan faces a real danger of becoming a failed state run by a regional narco-mafia.

The most serious internal threats to Kyrgyzstan's security are ethnic tensions and organized crime as amplified by regionalism, a clan-based society structure, pervasive corruption, and nepotism. Before the Russian conquest there were two main ways of life in Central Asia: settled and agricultural communities represented one lifestyle, while pastoral and nomadic groups represented the other. These lifestyles and cultural identities existed before the national labels were introduced by the Soviets, who gave locals rigid ethno-national identities and classified as them either Kyrgyz or Uzbeks. ${ }^{16}$

13 Rashid, Descent into Chaos, 331.

14 The major Central Asian transit hubs for heroin smuggling are Khujand (located in northern Tajikistan, close to the Uzbek and Kyrgyz borders) and Osh (located in southern Kyrgyzstan). See Alexandr Knyazev, "Kyrgyzstan and Russia: Security, Cooperation and Development Perspectives in the Central Asian Region," Eurasian Home (March, 2008): 15; available at http://www.eurasianhome.org/xml/t/expert.xml ?lang=en\&nic=expert\&pid=1484.

15 Erik Leijonmarck and Camilla Asyrankulova, "The Role of Organized Crime and Drug Trafficking in Kyrgyzstan's Ethnic Crisis," The Institute for Security \& Development Policy, Policy Brief No. 39 (13 October 2010): 1.

16 For example, the historically Turkic-speaking urbanized citizens of Osh were much more likely to have close kin relations with inhabitants of other Turkic-speaking urban centers along the Silk Road trade route such as Kashgar (located in the modern-day Chinese province of Xinjiang ) than they would with nomadic tribes who lived in what is now northern Kyrgyzstan or Uzbekistan. 
In the case of Kyrgyzstan it was incredibly difficult for the Soviet authorities to determine where exactly the borders of the Kyrgyz SSR should be. This difficulty gave birth to a popular theory that Stalin deliberately engineered local borders in order to generate ethnic unrest and prevent any Central Asian republic from becoming a viable independent state. Historically, the Kyrgyz people had no nation-state; its territory was a checkerboard of autonomous nomadic Kyrgyz tribes, settled valley communities, and towns in the Fergana Valley that paid allegiance to various khans and had mixed ethnic composition.

Today, there are a number of unresolved border issues that complicate bilateral relations in Central Asia. ${ }^{17}$ Many of these border disputes are located in and around the Fergana region, where the borders of Uzbekistan, Kyrgyzstan, and Tajikistan meet. The Kyrgyz-Uzbek border stretches for about 1300 kilometers, and there were more than thirty contested segments along this border. There are also two Uzbekistanadministered enclaves within the Batken Province of Kyrgyzstan. These enclaves, Sokh and Shakhimardan, hold a combined population between 40,000 and 50,000 people (in addition to the 750,000 to 1 million ethnic Uzbeks who live in Kyrgyzstan proper). ${ }^{18}$ In recent years, the relations between the ethnic Kyrgyz and Uzbeks have often been uneasy, and today represent a serious challenge to the internal stability of Kyrgyzstan. In June 1990, ethnic riots broke out in the Kyrgyz part of the Fergana Valley, in Osh and Uzgen. Traditionally mountain-dwelling Kyrgyz herdsmen demanded the redistribution of collective farmland from Uzbeks to a growing number of landless young Kyrgyz herders. Uzbek farmers protested, and the confrontation resulted in serious violence, with over 300 deaths, and was only stopped after a massive deployment of Soviet troops to the region. ${ }^{19}$ These socioeconomic tensions in the Fergana Valley had worsened during two decades of independence, and contributed to the new escalation of ethnic unrest in southern Kyrgyzstan in 2010.

The Kyrgyz part of the Fergana Valley is the least developed predominantly agricultural region of the country, with the highest rates of childbirth and unemployment, and is densely populated by a mixture of ethnic Uzbeks and Kyrgyz. ${ }^{20}$ Many local Kyrgyz men work abroad, and the remittances they send home are vital to the local economy. Uzbeks dominate agriculture and commerce in south Kyrgyzstan, while the recent global economic crisis has forced many young Kyrgyz migrant workers to

17 Stephane Lefebvre and Roger N. McDermott, "Russia and the Intelligence Services of Central Asia," International Journal of Intelligence and Counterintelligence 21 (2008): 256.

18 Sergey Luzyanin, Rossiya i Kitai v Evrazii: Mezhdunarodno-regional'nyye izmereniya rossiisko-kitaiskogopartnerstva (Moscow: ID "Forum," 2009), 62.

19 Hanks, Global Security Watch - Central Asia, 30.

20 “Q\&A: Kyrgyzstan's Ethnic Violence," BBC News (24 June 2010); available at http:// news.bbc.co.uk/1/hi/world/europe/10313948.stm. 
leave Russia and Kazakhstan and move back to Kyrgyzstan. The income gap between the two communities, in the midst of worsening socioeconomic conditions, contributed to an unprecedented level of ethnic tension between ethnic Kyrgyz and Uzbeks that resulted in recent ethnic riots. ${ }^{21}$

Ethnic tensions that threaten Kyrgyz stability also exist in northern Kyrgyzstan. Rural poverty and land shortages drove young Kyrgyz from the countryside into Bishkek (a predominantly Slavic city until the late 1980s), creating urban slums on the edge of the city and straining the urban infrastructure. This coincided with an upsurge of Kyrgyz nationalism, and led to the increasing hostility young and impoverished Kyrgyz felt toward the European, mostly Russian residents of Bishkek and its surroundings. ${ }^{22}$

Finally, organized crime is another major internal threat to Kyrgyzstan's security. This threat is often transnational in nature, and is closely correlated with external threats, including Islamist extremism and trafficking of Afghan heroin, both discussed above. Various Kyrgyz, Uzbek, Chechen, and Uighur criminal groups not only have informal control over major economic sectors in Kyrgyzstan, but are also represented in the highest echelons of political power. ${ }^{23}$ Kyrgyzstan's political opposition is known to rely on the quasi-military power of organized crime groups (often composed of former and active martial arts sportsmen), who played a key role in the so-called Tulip Revolution against President Akayev in 2005, and in the 2010 overthrow of President Bakiyev. ${ }^{24}$ Young, unemployed Kyrgyz men from urban slums or from impoverished rural and highland regions of Kyrgyzstan are easy targets for recruitment by criminal gangs. In April 2010, Kyrgyz unrest and the violent change of government prompted Kazakhstan and Uzbekistan to close their borders with Kyrgyzstan. These border closures brought to a halt commercial traffic that transits Kyrgyzstan, and intensified criminal competition for diminishing sources of income. ${ }^{25}$ These developments, along with ongoing ethnic tensions, contributed to the June

21 "10 Things You Need To Know About The Ethnic Unrest In Kyrgyzstan," Radio Free Europe/Radio Liberty (14 June 2010); available at http://www.rferl.org/content/10_Things_ You_Need_To_Know_About_The_Ethnic_Unrest_In_Kyrgyzstan/2071323.html

22 Alkan, "Post-Soviet Politics in Kyrgyzstan," 359.

23 Brothers Rysbek and Tynychbek Akmatbaevs, who led a powerful criminal syndicate (the so-called Issyk-Kul group), were deputies of the Jogorku Kengesh (Kyrgyz parliament). Janish Bakiyev, brother of former President Kurmanbek Bakiyev and the former chief of the State Security Service of Kyrgyzstan, was allegedly in control of narcotics trafficking in southern Kyrgyzstan. See http://www.eurasianet.org/ node/61591.

24 Marat, The Military and the State in Central Asia, 64.

25 "Uprising Worsens Kyrgyzstan Economic Woes," BBC News (13 April 2010); available at http://news.bbc.co.uk/2/hi/asia-pacific/8617199.stm. 
2010 unrest in the Osh and Jalal-Abad, regions where ethnic Kyrgyz criminal gangs attacked local Uzbeks and looted their property.

These ethnic and criminal security threats to Kyrgyzstan are amplified by entrenched regionalism, corruption, and nepotism, which are closely interconnected with the clan-based social structure of Kyrgyz society. The violent overthrow of the Akayev regime was to a large degree a response to the favoritism he showed towards his northern Sarybagysh clan, at the expense of all others. Likewise, the April 2010 uprising that forced President Bakiyev from power was in part a reaction of northerners against the entrenchment in the government of the Ichkilik clan coalition, which was dominated by his southern kin. ${ }^{26}$

Kyrgyz security structures have only limited ability to confront these multiple threats on their own, and Bishkek has often been forced to look for foreign help to deal with them. The most serious security challenges to Kyrgyzstan's integrity were the so-called Batken events of August 1999. Several hundred well-armed fighters belonging to the IMU attempted to infiltrate Uzbekistan`s Fergana region from Tajikistan via the remote Kyrgyz highland region of Batken. On 6 August 1999, Islamist fighters captured the akim (regional governor) of Batken and three police officers, and demanded passage across the Kyrgyz-Uzbek border. Kyrgyz authorities were stunned, and unable to cope with this security crisis on their own. After unsuccessful attempts to negotiate with the Islamist fighters, Bishkek allowed the Uzbek and Tajik armies to enter its territory in order to assist Kyrgyz security forces, and the Uzbek air force bombed the rebel positions in Batken. Soon after the Kyrgyz defense minister declared that as a result of a joint Kyrgyz-Uzbek military operation the rebels had been completely destroyed, IMU fighters entered several highland villages in Batken and captured a Kyrgyz commander of internal troops along with four Japanese geologists. Over the next few days, Kyrgyz forces engaged IMU fighters in a number of skirmishes, and the insurgents managed to capture several more villages. ${ }^{27}$

26 “Kyrgyzstan's Unrest Linked to Clan Rivalries," Eurasianet.org (4 June 2002); available at http://www.eurasianet.org/departments/insight/articles/eav060502.shtml.

27 Hanks, Global Security Watch - Central Asia, 32. 
The Kyrgyz armed forces were ill-equipped to fight in a remote mountain region against well-armed IMU fighters, who were battle-hardened by years of war experience in Afghanistan and Tajikistan. ${ }^{28}$

The security crises of 1999 demonstrated the vulnerability of Kyrgyzstan to external threats emanating from the neighboring lawless regions of Tajikistan and Afghanistan that became Central Asian breeding grounds of Islamist extremism and regional instability. Bishkek was unable to handle these challenges on its own, and was forced to look to Moscow and Tashkent for assistance. Because of Kyrgyz mistrust and fear of Uzbekistan - which Bishkek often suspected of irredentist claims to its part of the Fergana Valley, where a large Uzbek minority resides-Russia was a preferred security partner for Kyrgyzstan.

The aforementioned security threats present grave challenges to regional peace and stability. As will be argued below, none of the geopolitical actors operating in the region can resolve these problems individually. This calls for a cooperative solution to Central Asian security that cannot be realized without Russia's participation.

\section{Russia in Central Asia: Moscow's Efforts and Regional Responses}

Following a period of disinterest in Central Asia in early 1990s, Russia returned to the region. For Moscow, establishing a robust presence in Central Asia was a goal of major importance. The Kremlin inseparably linked Russian power on the international stage with a firm grip over the post-Soviet space. Accordingly, control over Central Asia's energy resources and transit routes were key elements in the Kremlin's

28 One year later, in August 2000, IMU fighters once again crossed the Tajik border and raided several Uzbek villages in the southern Surkhandarya province of Uzbekistan that borders both Tajikistan and Afghanistan. This IMU incursion was met with a massive and relatively well organized response by the Uzbek security forces. Within a few days, the IMU fighters were forced to leave most of the areas they had invaded. A large group of Islamist rebels fled into the Batken region of Kyrgyzstan. The first engagements between the Kyrgyz security forces and the insurgents were reported on 11 August 2000, and once again they demonstrated Kyrgyzstan's inability to deal with security threats on its own. Only the redeployment of the Russian military contingent in Tajikistan (201 ${ }^{\text {st }}$ Motor Rifle Division) from the Tajik-Afghan border to the TajikKyrgyz border forced the insurgents to retreat back to Tajikistan. The incursion of August 2000 resulted in a series of radical security measures taken by Tashkent. The population of the border villages in Surkhandarya province infiltrated by the IMU was deported, minefields were laid along the Uzbek borders with both Tajikistan and Kyrgyzstan (these mines are still killing and maiming many locals and their livestock). Central Asia: Border Disputes and Conflict Potential, ICG Asia Report No. 33 (4 April 2002), 4. 
quest for geopolitical power. The threats of Islamist extremism and drug flows emanating from the region posed serious challenges to Russia's security and stability. Moscow was also concerned with the fate of the large ethnic Russian minority that lives in the region. ${ }^{29}$

These considerations brought Russia in the regional security loop. The return to Central Asia was a complex matter, rife with both advantages and challenges. To accomplish its regional objectives, Russian policymakers decided to pursue the formation of a collective security regime for Central Asia, with Russia at the helm. This regime had an essentially integrationist character, where the region was treated as a holistic entity. In Moscow's vision, an integrative approach was a more efficient way of regaining sway over Central Asia than a policy oriented at relations with individual states. Moscow policymakers considered the latter inefficient, because in their view a centralized, top-down approach was a better means of both managing Russian scarce resources and making Central Asian states comply with Russian initiatives. Accordingly, the individual aspects of the Central Asian states were viewed primarily as factors that had to be taken into consideration in the design of joint approaches. ${ }^{30}$

Russia did not plan on pursuing any political changes in Central Asia, preferring to deal with existing elites, rather than actively promoting transformations of the regional status quo. Russia treated regional political and cultural specificities as given factors that had to be accounted for in policy planning, rather than variables that should be changed through regional engagement. This was a distinctly functionalist approach that focused on common interests and needs. Such a perspective allowed Russia to pursue joint projects with Central Asian states, while avoiding tensions in its dialogue with the regional establishment. While this approach granted Moscow more flexibility in its regional activities, it also tacitly perpetuated inefficiencies in Central Asian governance. This remains the weakest part of the Russian regional policy to date.

To proceed further, Moscow needed regional "footholds"- countries that would be active participants in Russia's security projects, serving as anchors in the area. Russia's main regional partners in security matters in the 1990s were Uzbekistan and Kazakhstan. Having the strongest military force among all the Central Asian states, Uzbekistan was initially the most desirable candidate for this role. However, the appeal of Uzbek military might was overshadowed by its intransigence in terms of Russian regional policy. Tashkent had ambitions to be a regional power of its own, and refused to acknowledge Russia's leadership in Central Asia. Uzbekistan

29 Joseph P. Ferguson, "Russian Strategic Thinking Towards Central, South, and Southeast Asia," in Russian Strategic Thought Towards Asia, ed. Gilbert Rozman, Kazuhiko Togo, and Joseph P. Ferguson (New York: Palgrave Macmillan, 2006), 207.

30 Vladimir Paramonov, Aleksey Strokov, and Oleg Stolpovski, Russia in Central Asia: Policy, Security and Economics (Hauppauge, NY: Nova Science Publishers, 2009), 2-5. 
approached security cooperation with Russia on an ad hoc basis, occasionally joining Russian-backed security initiatives, but always ready to withdraw its participation. ${ }^{31}$ For Russia, security and military cooperation with Kazakhstan was (and remains to this day) strategically very important, since the states have a long common border. Kazakhstan established close military and security ties with Russia, and joined the Collective Security Treaty Organization (CSTO) and other Russian-backed security initiatives. However, Kazakh participation was not enough to usher in a comprehensive, "whole region" security approach.

Turkmenistan, Tajikistan, and Kyrgyzstan were other potential candidates to serve as Russian regional footholds in Central Asia. These nations inherited smaller pieces of the Soviet military pie, and lacked the human and materiel resources to develop strong security mechanisms. ${ }^{32}$ At the same time, they were on the front lines of the growing drug trafficking and extremist threats emanating from Afghanistan.

Out of these three states, Turkmenistan preferred to keep its military and security relations with Russia to a minimum. Turkmenistan persistently refused to participate in Commonwealth of Independent States (CIS) military cooperation agreements, pursuing a policy of "permanent neutrality." In the 1990s, Turkmen-Russian military and security relations were limited to Russia's patrolling of the Turkmen-Afghan border and occasional purchases of Russian hardware by the Turkmen military. In 1999, the remaining Russian border guards withdrew from Turkmenistan, and Ashgabat became the only Central Asian state to establish a cordial relationship with the Taliban regime in Afghanistan. ${ }^{33}$ Consequently, Turkmen security cooperation with Russia and other Central Asian states came to a virtual halt.

Tajikistan was the most serious test for Russian security policy in Central Asia. Between 1993 and 1997, Russian peacekeeping troops were deployed in the midst of this country's civil war. While the Russian peacekeeping operation succeeded in brokering peace between the Islamist opposition forces and the central government in Dushanbe, some security issues remained unsolved. In particular, Moscow was unable to forge security cooperation between Uzbekistan and Tajikistan. Relations between the two countries remain tense, with negative implications for Central Asian

31 In 1999, Uzbekistan withdrew from the CIS Collective Security Treaty (CST) and joined the GUAM group, established in 1997 by Georgia, Ukraine, Azerbaijan, and Moldova in order to counter Russian influence in the former Soviet realm. In 2005, Uzbekistan withdrew from GUAM , and joined the CSTO in 2006. Paramonov, Strokov, and Stolpovski, Russia in Central Asia, 1-10.

32 Marat, The Military and the State in Central Asia, 55

33 Vladimir Georgiev, "Turkmeno-afganskaya granitsa mozhet stat' bezkontrol'noi," $\mathrm{Ne}$ zavisimaya Gazeta (25 December 1999) ; available at http://www.ng.ru/cis/1999-1225/242_53.html 
security. ${ }^{34}$ After 1997, Russian troops remained in Tajikistan to maintain the fragile peace in the country and safeguard it from threats emanating from Afghanistan. Tajikistan embraced Moscow's security initiatives in the region, and became highly dependent on Russian security assistance.

Kyrgyzstan was an attractive option for Russia to establish a foothold in the region and serve as an anchor for its security projects. In the 1990s, Kyrgyzstan remained relatively stable. While geographically situated in a strategic location bordering China and all Central Asian states expect for Turkmenistan, it also controlled the highlands that surround the Fergana Valley - the heart of Central Asia. Kyrgyzstan's strategic location provided the possibility to contain the Islamist extremist and narcotrafficking threats emanating from Afghanistan and Tajikistan. Most importantly, the Kyrgyz authorities - who clearly realized the extent of the looming challenges they faced - welcomed Russia as a guarantor of their national security. ${ }^{35}$

Russia's policy toward Central Asia received a new lease on life in 1999, when the Russian posture in the region became the focus of attention of the new Russian Prime Minister Vladimir Putin. Putin masterfully seized the opportunity created by the Batken events. ${ }^{36}$ In a brisk and decisive manner, Putin promoted Russia as the key security actor in Central Asia due to Russian military and anti-terrorist expertise and knowledge of the region. Conceptually speaking, Putin made the anti-terrorist agenda a cornerstone for a larger security discourse that would justify a larger Russian political and military presence in the area. ${ }^{37}$ The Kremlin's new agenda for Central Asia was developed in order to slow down the erosion of Russian influence in the region, at the same time as Russian military advisors and troops were being largely phased out of the Central Asian states. By 2000, the only two countries that retained Russian contingents were Tajikistan and Kyrgyzstan. In Tajikistan, Russian border troops continued patrolling CIS borders; in Kyrgyzstan, Russian military advisors were still deployed along the Kyrgyz-Chinese border. ${ }^{38}$

34 Vyacheslav Belokrenitsky, "Russian-Afghan Relations," in Russia and Asia: The Emerging Security Agenda, ed. Gennady Chufrin (Stockholm: Stockholm International Peace Research Institute, 1999), 205; available at http://books.sipri.org/files/books/SIPRI99Chu/ SIPRI99Chu13.pdf.

35 Alexandr Knyazev, "Kyrgyzstan and Russia: Security, Cooperation and Future Perspectives," Historical Perspectives Fund, (2008); available at http://www.perspektivy.info/ oykumena/krug/kirgizija_i_rossija_bezopasnost_sotrudnichestvo_i_perspektivy_ razvitija_v_centralnoaziatskom_kontekste_2008-03-21.htm

36 Bakhrom Tursunov and Marina Pikulina, "Severe Lessons of Batken," Defence Academy of the United Kingdom, Conflict Studies Research Centre, Paper K28 (November 1999); available at www.da.mod.uk/colleges/arag/document-listings/ca/K28.

37 Lena Jonson, Vladimir Putin and Central Asia (London: I. B. Tauris, 2004), 81-83.

38 "Russia and Central Asia," The NATO-Russia Archive (18 November, 2005); available at http://www.bits.de/NRANEU/CentralAsia.html. 
Russia's determination to restore its flagging regional influence was stated in the Foreign Policy Concept of the Russian Federation of June 2000, which featured a balanced menu of bilateral tactical agreements along with a strategic multilateral approach.$^{39}$ At the same time, Moscow continued to abstain from linking its security guarantees with political transformations in the region, which reinforced its message in Central Asian capitals.

As much as the new version of regional security justified a Russian presence in Central Asia, it denied the West a right to be there. Countering Western activities in Russia's "back yard" was a pronounced feature of Putin's policy recipe for the region. This mindset precluded any alliances with Western powers in the region, resulting in Russia adopting a zero-sum logic in its Central Asian security enterprises..$^{40}$

Russian efforts to regain regional influence started to bear fruit in the wake of the terrorist attacks in the U.S. in September 2001. At that time, the U.S. and NATO stepped up their regional presence as a result of their operation in Afghanistan. Russia's resolve to reestablish itself in Central Asia, as well as the changing security situation in the region, boosted Moscow's security projects. ${ }^{41}$ Despite the faltering status of the CIS, Russia managed to convince Armenia, Belarus, Kazakhstan, Kyrgyzstan, and Tajikistan to upgrade their cooperation, which resulted in the creation of the Collective Security Treaty Organization in May 2002. The organization offered a means of preserving the territorial integrity and security of the members, means that were primarily based on Russian proposals. Russia also expanded its military cooperation in the region. This gave Moscow the right to use a variety of military infrastructure objects located in Central Asia. Among other things, this includes the Baikonur spaceport in Kazakhstan, the Nurek space surveillance center in Tajikistan, and the Kant air base in Kyrgyzstan. These countries also agreed that Russia would be allowed to modernize their national anti-missile defense systems. ${ }^{42}$

Russia and China managed to arrive at a shared vision regarding the evolution of the Shanghai Five, which was officially inaugurated as the Shanghai Cooperation

39 The Foreign Policy Concept of the Russian Federation (28 June 2000); available at http:// missions.itu.int/ russia/concept_doc.htm.

40 Ibid.

41 Ibid., 93-98.

42 Vladimir Paramonov and Oleg Stolpovski, "Russia and Central Asia: Bilateral Cooperation in the Defence Sector," Defence Academy of the United Kingdom, Advanced Research and Assessment Group, Central Asian Series, 08/15(E) (2008); available at www. da.mod.uk/colleges/arag/document-listings/ca/08(15)VPEnglish.pdf. 
Organization (SCO) during a summit in China on 15 June 2001. ${ }^{43}$ This evolution improved the mechanisms and policies of the organization, thus promoting Russiabacked collective security solutions for Central Asia. It is important to note that at this stage neither of the newly formed organizations was driven by any anti-Western sentiment. The driving factors behind this cooperation were shared security concerns, such as threats emanating from the Taliban-controlled areas of Afghanistan. ${ }^{44}$ Russia and China were ready to accept a Western presence in Central Asia, since NATO's anti-Taliban operation in Afghanistan was beneficial to their own security.

The upgraded collective institutions, however, did not result in an increased commitment on the part of the Central Asian member states, which maintained an equidistant stance in their foreign relations in order to maximize their options. Moreover, as the U.S. stepped up its military presence in the region, it gradually started to challenge Russia's touted status as the sole guarantor of regional security and defense.

The Republic of Kyrgyzstan is a clear example of this trend. Recognizing its vulnerability to Islamist extremism and drug trafficking, Bishkek consistently sought support from foreign powers on taking the precautionary measures necessary to tackle threats to regional security and stability. Kyrgyzstan opened its doors to both Russian forces and the U.S. military, which raised the nation's profile in Central Asian security among external and regional actors. In these circumstances, Russia began to lose its monopoly on regional security. This represented a major challenge for Moscow, since it could not increase its own military presence or political influence in Central Asia, as the local establishments preferred to balance their foreign policy leanings to avoid excessive dependence on one power. ${ }^{45}$

Such attitudes toward Russia-supported security alliances were illustrated by the conduct of the Central Asian states after the Russian war with Georgia in August 2008. None of the SCO or CSTO member states recognized the independence of Sou-

43 The Shanghai Five was the SCO's predecessor, and originated and grew from the endeavor by China, Russia, Kazakhstan, Kyrgyzstan, and Tajikistan to strengthen confidencebuilding and disarmament in the border regions. For an in-depth analysis of the SCO's role in Central Asia security, see Zhao Huasheng, "Security Building in Central Asia and the Shanghai Cooperation Organization," Slavic Research Center, (2004); available at $s r c-h$. slav.hokudai.ac.jp/coe21/publish/no2_ses/4-2_Zhao.pdf.

44 S. Poia, "SCO Can Benefit from Afghan Membership," Vse ob Afghanistane (16 June 2007); available at http://www.afghanistan.ru/doc/9291.html.

45 Many Central Asian rulers treat Russian assertions of power in the region with caution, as they are afraid of an imperial resurgence on the part of Moscow. At the same time, they realize the utility of Russian security guarantees, or use Russian security offers as bargaining chips in their relations with another power, most often the U.S. Russia-Kyrgyz relations are a telling example of this dynamic. For more details, see Hooman Peimani, Conflict and Security in Central Asia and the Caucasus (Santa Barbara, CA: ABC-Clio, 2009), 145-48. 
th Ossetia and Abkhazia, the territories that Moscow ostensibly sought to liberate. ${ }^{46}$ The ongoing economic crisis brought with it a new set of challenges and opportunities for Russia. ${ }^{47}$ On the one hand, the Central Asian states whose economies were hit hardest by the crisis became more willing to cooperate with Moscow in exchange for financial support. On the other hand, Russia was not in the position to offer substantial aid to its Central Asian partners, as its national economy was hit hard as well. Nevertheless, Russia managed to give crisis-stricken Kyrgyzstan a USD 2 billion loan and USD 150 million in direct aid. Moscow also was a key participant in the realization of a joint action plan of the Eurasian Economic Community (EurAsEc), an economic organization that at present includes Russia, Belarus, and all Central Asian states, except Uzbekistan and Turkmenistan. Today, Russia is a principal donor to the EurAsEc anti-crisis fund, to which it will contribute USD 7.5 billion (out of a total of USD 10 billion).

Current economic difficulties have forced Russia to refrain from using economic tools in its security pursuits. Instead, Russia went back to its trusted tools, and relied on its military and anti-terrorist expertise to bolster collective regional projects. This time, Russian authorities concentrated on arriving at a common understanding with their Central Asian counterparts on key threats and the steps needed to tackle them. In the CSTO, Russia stepped up joint military training and regular meetings of senior officers and experts from the member states. ${ }^{48}$ This approach bore fruit during the CSTO summit in Moscow in June 2009, when Russia reaffirmed its commitment to Central Asia by signing the Agreement on a CSTO Collective Operational Reaction Force and by starting work on its creation. This shows that Moscow has learned from its past policy blunders and is trying to forge a collective regional regime that will accommodate different perspectives in strengthening Central Asian security and stability.

Also, in support of its Central Asia agenda, Russia used its chairmanship of the SCO to steer the group toward a more active role in addressing the conflict in Afghanistan and its associated problems, such as drug trafficking and terrorism. ${ }^{49}$ There

46 Elizabeth Wishnick, "China's Challenges in Central Asia," PONARS Eurasia Policy Memo No. 73 (September 2009); available at http://ceres.georgetown.edu/esp/ ponarsmemos/page/78378.html.

47 An overview of the challenges posed by the economic crisis to Russian foreign policy (including its CIS vector) has been examined by the Centre for European Policy Studies (CEPS) in Stanislav Secrieru, "Russian Foreign Policy in Times of Crisis: Greater Compliance or Resilient Self-confidence?" CEPS Policy Brief No. 192 (30 June 2009). Ibid.

49 For more details, see "Main SCO Events in 2009," The Shanghai Cooperation Organization (2009); available at http://www.sectsco.org/RU/show.asp?id=346. 
is a growing understanding among Russian authorities on the need for cooperation with the Western powers operating in Central Asia to contain regional security problems. ${ }^{50}$

As of now, however, neither the SCO nor the CSTO has undertaken any practical steps to engage the U.S. in a dialogue on regional security. The U.S. has also not been forthcoming in initiating cooperation with the two regional organizations. ${ }^{51} \mathrm{As}$ follows from the recent report of the Carnegie Council, "the United States and NATO prefer to develop cooperation with the Central Asian nations ... while 'not noticing' counter-proposals from the Russian side and their colleagues in SCO and CSTO." 52 The status quo is unacceptable today, when the security situation in Central Asia is deteriorating, and, as will be shown below, the West is not capable of dealing with it on its own.

\section{The West in Central Asia: Western Initiatives and Regional Realities}

Western security cooperation with Central Asia commenced with the collapse of the USSR. At that time, NATO signed bilateral Partnership for Peace (PfP) agreements with all of the Central Asian states. This allowed the Central Asian nations to build bilateral relations with the Alliance and participate in military cooperation with NATO. The Alliance's objectives included preventing regional hegemony, maintaining access to Central Asian energy resources, reducing conflicts, and containing Islamist extremism in the region. Western policymakers based their initiatives on the assumption that the Central Asian nations would quickly adopt Western values and norms, thus facilitating the accomplishment of NATO security objectives. Because of this perspective, NATO neglected individual differences between the states, lumping together Central Asia and the Caucasus in its regional policy.

In the wake of 9/11 and the ensuing Afghan campaign, the Alliance stepped up its regional involvement. This happened because some NATO members, most particularly the U.S., considered the region a key to their own security. However, a continu-

50 Yuri Morozov, "Prospects for U.S.-Russia Cooperation in Central Asia," Carnegie Council Papers (17 August 2009); available at http://www.cceia.org/resources/articles_papers_ reports/0031.html.

51 There is no consensus as to why the U.S. keeps its distance from these regional security organizations. Some experts say that the status quo is due to the grand ambitions of the U.S. that wants to become the major power in the region to control its energy riches. Others would point to veiled anti-Americanism on behalf of Russia and China that "repels" U.S. involvement.

52 Morozov, "Prospects for U.S.-Russia Cooperation in Central Asia." See also Greg Granger, "Russian Reactions to U.S. Foreign Policy," American Diplomacy (23 April 2007); available at http://www.unc.edu/depts/diplomat/item/2007/0406/gran/granger_russia.html. 
ed insistence on adopting Western values and a poor knowledge of regional history and culture limit the progress of Western security initiatives in Central Asia. The Western reaction to the Andijon events in Uzbekistan in 2005 clearly illustrated this problem. A large number of protestors who were attempting to seize a local jail were killed by Uzbek security forces in this city in the Fergana region. The EU and the U.S. criticized Tashkent for human rights violations. While these statements changed nothing in the Uzbek human rights situation, they resulted in the loss of use of the Karshi-Khanabad air base in Uzbekistan. After this, the Manas air base in Kyrgyzstan became even more critical in providing logistics support for the Afghan campaign. To maintain its presence, the U.S. now must stay on the good side of the Kyrgyz establishment. This effectively limits Washington's scope of involvement in Kyrgyz security, since any measure that is not welcomed by Bishkek can complicate the base's functioning, or even result in the expulsion of the U.S. military. This was confirmed during the Kyrgyz crisis in 2010, when the U.S. offered humanitarian assistance to displaced families in southern Kyrgyzstan, but refrained from taking practical steps to end the violence. ${ }^{53}$

The aforesaid deficiencies reduce the effectiveness of Western security policy toward Central Asia. This is one of the reasons why, despite the signing of PfP agreements with Central Asian states in the mid-1990s and a greater regional presence, NATO is still unable to leverage any collective regional security efforts through the PfP framework. Today, as the Afghan campaign draws ever increasing amounts of personnel and materiel, NATO and the U.S. are even less likely to allocate limited resources to address Central Asian security challenges. To sum up, the value-based approach adopted by the West exhausted itself for a number of reasons. First, it ignores the deeply ingrained realities of the region, where authoritarianism has had a long historic record. Second, the West lacks any feasible instruments to enforce its values without risking its existing relations with Central Asian states. ${ }^{54}$ These structural limitations, as well as the inability of both Russian and Western-backed regional security initiatives to resolve regional security challenges individually, became evident during the Kyrgyz crisis of 2010.

53 U.S. Department of State, "U.S. Response to Crisis in Kyrgyz Republic, Uzbekistan," (17 June, 2010); available at http://www.america.gov/st/texttrans-english/2010/June/2010061 7144440SBlebahC0.190437.html.

54 For more details, see Simon J. Smith and Emilian Kavalski, "NATO's Partnership with Central Asia: Cooperation a la carte", in The New Central Asia: the Regional Impact of International Actors, ed. Emilian Kavalski (Singapore: World Scientific Publishing Co., 2010), 29-49. 


\section{The Kyrgyz Crisis of 2010: The Burst of Violence and Inefficient Security Arrangements}

The global economic crisis started to seriously affect the Kyrgyz economy in 2009. The crisis forced many Kyrgyz migrant workers to leave Russia and Kazakhstan and move back to Kyrgyzstan. In April 2010, a wave of unrest originated in the northwestern town of Talas, and quickly spread to the capital. President Bakiyev ordered police and Special Forces to fire on the crowds of protestors who surrounded the presidential residence on 7 April 2010. The unrest in the north initially did not spread to the south. Small protests by Bakiyev loyalists in Osh and Jalal-Abad subsided after the president fled the country. However, border closures and the change of government in Bishkek enraged criminal elements in the south that controlled the cross-border smuggling and drug trade, and had close ties to Bakiyev regime. Between 9-15 June 2010, gangs of young Kyrgyz men looted ethnic Uzbek property and forced many Uzbeks to flee, leaving their houses, businesses, and land. Official figures put the number of dead in the riots at 893 , with unofficial estimates claiming that more than 2000 people died in the violence. Neither of the regional collective security mechanisms was able to prevent the escalation of violence in Kyrgyzstan. CSTO, SCO, NATO, and OSCE all failed to take any practical steps to end the violence or to ensure that the unrest will not be repeated. The situation in southern Kyrgyzstan remains volatile, and another wave of ethnic violence can happen at any time. The existing collective security arrangements have been proven to be ineffective, and the dire need for security assistance to Kyrgyzstan was exposed. As will be discussed below, these dramatic events in Kyrgyzstan could be a harbinger of a chain of region-wide security crises in Central Asia that demand a viable security response.

\section{The Future Of Central Asia: Unresolved Challenges And Upcoming Th- reats}

The future of Central Asia as a whole and Kyrgyzstan in particular is highly uncertain. There is no shortage of doomsday scenarios in the region. There are several factors that can have grave consequences for the future of Central Asia. They include the possible implications of Western failure in Afghanistan, which could potentially lead to the return to power of the Taliban. This would provide a great morale boost to Central Asian Islamists, including the IMU, Hizb ut-Tahrir, and the Tajik Islamist opposition, who can relatively easily reignite the civil war in Tajikistan, which in turn would threaten the stability of Kyrgyzstan and Uzbekistan. Even more dangerous is the potential state failure in a nuclear-armed Pakistan, which is bound to send tidal waves of instability throughout South and Central Asia. The succession issue is another potentially destabilizing issue in Central Asia. Uzbekistan, Tajikistan, and 
Kazakhstan are all run by ailing autocratic leaders who seem to have no smooth plans in place for the transfer of power. Of special concern is Uzbekistan, where the death of its dictatorial President Islam Karimov will most likely result in a scramble for power among its inner circle. Any future successor of Karimov will have to act quickly to reassert Tashkent's authority over its restive population; another Andijonlike incident in the Fergana Valley could flood southern Kyrgyzstan with Uzbek refugees, and potentially spark a new wave of ethnic unrest or even provoke a civil war in Kyrgyzstan. Any one of these possible future events can trigger destabilization of the entire Central Asian region.

\section{Conclusion: Scenarios for Future Cooperation}

Today Central Asia is a territory riddled with numerous stability and security problems. This article illustrated the inability of the powers operating in the area to deal with these challenges on their own. For the stabilization of Central Asia, these powers need to combine their individual resources, experiences, and capacities in a collective regional solution. Formerly, such a joint effort was not feasible due to the "zero-sum" mentalities of the regional actors. Today, when the relationship between Moscow and the West is improving, this much-needed condition can finally be realized. Russia reconciled itself to the Western presence in Central Asia and developed a more flexible regional policy that opens up new possibilities in Central Asia. In the new format, Russian experience in regional programming can be employed in setting up a joint security framework.

As was discussed above, Russia's Central Asia policy is built on functionalism and collectivism. Unlike the West, Russia does not base its regional posture on trying to convince Central Asian leaders to change their governance patterns. This approach has both positive and negative aspects. On the one hand, it did facilitate the development of Moscow's security programs in Central Asia. On the other hand, it contributed to preserving regional political inefficiencies. At the same time, the Western value-based strategy did not produce much in the way of democratization, but did limit opportunities for cooperation between Western actors and the Central Asian establishment.

Placing human rights issues at the forefront of its relations with Central Asian regimes while downplaying or ignoring their concerns about terrorist threats in Central Asia has had a detrimental effect on Western cooperation with Kyrgyzstan and other countries in the region. As was shown above, Kyrgyzstan's heavy-handed approach and human rights violations in its struggle against extremists is often an indication of its dire lack of resources, including proper counterterrorist training and the funding needed to confront multiple challenges to its national security. The emphasis on counterterrorist cooperation rather than human rights critiques will also help to bring about closer cooperation with Russia (as well as China), which already provides assistance in counterterrorism efforts to Bishkek. 
Therefore, a viable solution to the challenges of Central Asian security must be based on an approach that would synthesize value-based and functionalist perspectives. To achieve maximum effect, these approaches should be combined in a comprehensive policy package. In this domain there is significant potential for cooperation between foreign and local stakeholders in regional security. The areas of cooperation must concentrate on the most acute Central Asian security problems, such as drug trafficking and Islamist extremism. This can be based on a joint peacekeeping framework that will bring together Russia, China, the U.S., and the EU. Within this framework, the parties can share experience and best practices, conduct collective training exercises, and work out collective crisis management solutions. In particular, the U.S. and NATO members operating in the region can share their experience in civilmilitary cooperation and development assistance, while Russia can offer its practical knowledge and understanding of Central Asian culture and history to facilitate regional peacekeeping efforts. The CSTO can become a primary vehicle of such missions, since this organization already has designated peacekeeping as an integral part of its mandate.

In the area of drug trafficking prevention, the CSTO, SCO, and NATO can establish a joint strategy for securing regional drug distribution channels. Joint programs can be launched to supply necessary equipment and training to border guards and support them with NATO and CSTO experts and Special Forces in counter-narcotics operations. Similar measures will also be effective against Islamist extremists operating in Central Asia. To further this cooperation agenda, CSTO, SCO, and NATO members can establish a shared database on regional security challenges to exchange up-to-date intelligence and to provide it to security services in the Central Asian states. To eliminate the underpinnings of the regional security issues, the cooperating parties must also align their policies with respect to Afghanistan. This should include developing a concerted vision of how to assist the Afghan government in tackling narcotics and extremist issues, as well as in improving socio-economic conditions in Afghanistan more generally.

These ideas suggest some possible ways of engaging Russia in the development and realization of joint regional security programs. Actual cooperation scenarios will require an in-depth analysis and consultations between the states and the organizations that have a stake in Central Asian security. As the Kyrgyz crisis has clearly shown, no single regional actor can guarantee Central Asian peace and stability on its own. Accordingly, the West should no longer view Russia as a strategic competitor, but rather should engage Moscow in joint projects to produce a long-overdue viable security solution for Central Asia. 


\section{Bibliography}

10 Things You Need To Know About The Ethnic Unrest In Kyrgyzstan. Radio Free Europe/Radio Liberty, 2010.

Alkan, Haluk. "Post-Soviet Politics in Kyrgyzstan: Between Centralism and Localism?" Contemporary Politics 15, no. 3 (2009): 358.

Belokrenitsky, Vyacheslav. "Russian-Afghan Relations." In Russia and Asia: The Emerging Security Agenda, 205. Stockholm: Stockholm International Peace Research Institute, 1999.

Blank, Stephen. "The Strategic Importance of CA: An American View." Parameters (2008): 78.

Brzezinski, Zbignew. The Grand Chessboard: American Primacy and its Geostrategic Imperatives. New York: Basic Books, 1997.

Central Asia: Border Disputes and Conflict Potential In ICG Asia Report., 2002.

Collins, Kathleen. Clan Politics and Regime Transition in Central Asia. New York: Cambridge University Press, 2006.

Ferguson, Joseph P.. "Russian Strategic Thinking Towards Central, South, and Southeast Asia." In Russian Strategic Thought Towards Asia, 207. New York: Palgrave Macmillan, 2006.

Georgiev, Vladimir. "Turkmeno-afganskaya granitsa mozhet stat' bezkontrol`noi." Nezavisimaya Gazeta (1999).

Granger, Greg. "Russian Reactions to U.S. Foreign Policy." American Diplomacy (2007).

Hanks, Reuel R.. Global Security Watch - Central Asia. Santa Barbara, CA: ABC-CLIO, 2010.

Huasheng, Zhao. Security Building in Central Asia and the Shanghai Cooperation Organization. Slavic Research Center, 2004.

Ivanov, I.S.. "The Foreign Policy Concept of the Russian Federation." In The New Russian Diplomacy. Washington, D.C.: The Nixon Center and Brookings Institution Press, 2002.

Jonson, Lena. Vladimir Putin and Central Asia. London: I. B. Tauris, 2004. 
Knyazev, Alexandr. Kyrgyzstan and Russia: Security, Cooperation and Development Perspectives in the Central Asian Region. Eurasian Home, 2008.

Knyazev, Alexandr. Kyrgyzstan and Russia: Security, Cooperation and Future Perspectives In Historical Perspectives Fund., 2008.

Kyrgyzstan's Unrest Linked to Clan Rivalries. Eurasianet.org, 2002.

Lefebvre, Stephane, and Roger N. McDermot. "Russia and the Intelligence Services of Central Asia." International Journal of Intelligence and Counterintelligence 21 (2008): 256.

Leijonmarck, Erik, and Camilla Asyrankulova. The Role of Organized Crime and Drug Trafficking in Kyrgyzstan's Ethnic Crisis In Policy Brief. The Institute for Security \& Development Policy, 2010.

Luzyanin, Sergey. Rossiya i Kitai v Evrazii: Mezhdunarodno-regional'nyye izmereniya rossiisko-kitaiskogo partnerstva. (Moscow: ID "Forum”, 2009.

Main SCO Events in 2009. The Shanghai Cooperation Organization, 2009.

Marat, Erica. The Military and the State in Central Asia: From Red Army to Independence. London: Routledge, 2010.

Morozov, Yuri. Prospects for U.S.-Russia Cooperation in Central Asia In Carnegie Council Papers., 2009.

Paramonov, Vladimir, Aleksey Strokov, and Oleg Stolpovski. Russia in Central Asia: Policy, Security and Economics. Hauppauge, NY: Nova Science Publishers, 2009.

Paramonov, Vladimir, and Oleg Stolpovski. Russia and Central Asia: Bilateral Cooperation in the Defence Sector In Central Asian Series. Defence Academy of the United Kingdom, Advanced Research and Assessment Group, 2008.

Peimani, Hooman. Conflict and Security in Central Asia and the Caucasus. Santa Barbara, CA: ABC-Clio, 2009.

Poia, S.. "SCO Can Benefit from Afghan Membershipt." Vse ob Afghanistane (2007).

Q\&A: Kyrgyzstan's Ethnic Violence. BBC News, 2010.

Rashid, Ahmed. Descent into Chaos: The United States and the Failure of Nation Building in Pakistan, Afghanistan, and Central Asia. New York: Viking, 2008.

Russia and Central Asia. The NATO-Russia Archive, 2005. 
THE QUARTERLY JOURNAL

Secrieru, Stanislav. Russian Foreign Policy in Times of Crisis: Greater Compliance or Resilient Self-confidence? In CEPS Policy Brief., 2009.

Smith, Simon J., and Emilian Kavalski. "NATO's Partnership with Central Asia: Cooperation a la carte." In The New Central Asia: the Regional Impact of International Actors, 29-49. Singapore: World Scientific Publishing Co., 2010.

Tursunov, Bakhrom, and Marina Pikulina. Severe Lessons of Batken In Conflict Studies Research Centre. Defence Academy of the United Kingdom, 1999.

U.S. Response to Crisis in Kyrgyz Republic, Uzbekistan. U.S. Department of State.

Uprising Worsens Kyrgyzstan Economic Woes. BBC News, 2010.

Wishnick, Elizabeth. China's Challenges in Central Asia In PONARS Eurasia Policy Memo., 2009. 